\title{
PROTECTING THE USER INTEREST IN RAILROAD REORGANIZATION
}

\author{
Armibtrad B. Rood*
}

I

The typical railroad reorganizations before the enactment of Section 77 in 1933 did not adversely affect the public interest in transportation service. Receivership machinery went into motion as soon as earnings and credit had become insufficient to pay junior fixed charges, but while there was still enough to cover operating expenses, taxes, joint facility rents, senior bond interest and rent for leased roads. By cutting down those fixed charges junior to all these prior charges the receivership eased the pressure on the earnings and thus safeguarded the prior charges and the integrity of operation and service. By deferring or reducing to stock category large junior principal debts incurred by the road to augment facilities, the typical reorganization enabled railroad users to enjoy those facilities without paying for them.

For these reasons and because reorganization customarily toned up management and made up for deferred maintenance, receivership usually benefited the public interest automatically. Hence this interest received no special attention in the receivership proceedings which were deemed mere debtor-creditor affairs that would give the public interest due recognition simply by producing a reorganized debt structure sound enough to enable the road to command new capital requirements cheaply.

Reorganizations are now cutting deeper. Current plans proposed under Section 77 freely upset rights of senior creditors. Foreclosures and collateral sales are prevented, leases are rejected, stockholders are obliterated. Sub-section (b) requires new capital structures to conform more strictly to conservative estimates of future earning pawer, regardless of valuations. The new rigor has engendered new pressures to keep security holders' sacrifices to minimums by conserving assets and developing maximum income estimates.

Only two ways exist to increase earnings: by raising revenues and cutting expenses. Depression, industrial relocations, and expanding resort to non-rail transport have blighted opportunities for increasing traffic and rates, the components of

- A.B., r931, LL.B., 1938, Harvard University. Executive Research Director of the Old Colony Commuters \& Shippers League. Assistant counsel to the subcommittee of the U. S. Senate Committee on Interstate Commerce investigating railroad finances and related matters, $1935-1937$.

The problem of the user interest has been made specific in this article by reference to pending proceedings, including discussion of issues in controversy therein. As to these proceedings the writer is not disinterested, and his presentation of those issues should be read with that fact in vien. 
revenue. Operating expenses are chiefly for labor and supplies. The mere bankruptcy of a purchaser does not normally reduce the cost of its supplies. Wage levels, which average $7 \frac{1}{2}$ or $8 \%$ above 1929 levels, can be reduced no more easily by a road in Section 77 than by a solvent road, for subsection $(n)$ forbids judges and trustees from changing wages or working conditions except as prescribed in the Railway Labor Act. ${ }^{1}$ Little hope of increasing earnings lies through tax reductions; in fact social security objectives have imposed new taxes.

Faced by these barriers, those in charge of reorganizations direct their attention to those services which every large railroad operates as a public accommodation, and which alone do not earn their separate costs. The entire passenger service pays on only a few roads, and on none of these does every passenger train and every stop pay. Moreover, alt railroad systems are consolidations of numerous small roads, and as systems consolidate they concentrate through traffic onto one line and dry up duplicate services for system economy. Thus the trend is for fewer segments to receive the support of through traffic for losing accommodating services. The losing services, passenger and freight, are therefore increasingly vulnerable to attack under the new pressure of the severe reorganizations.

\section{II}

Yet the most important interest in railroads, however, is not the interest of the stockholders, bondholders, labor, or tax-collectors, however public these now may be. The original and primary interest in railroads is the public interest in railroad use and service, which has always received legal protection under two theories.

I. Through common law recognition of public dependence on service. The ancient attitude was classically restated by Chief Justice Waite in Munn v. Illinois:"

Property does become clothed with a public.interest when used in such a manner to make it of public consequence, and affect the community at large. When, therefore, one devotes his property to a use in which the public has an interest, he, in effect, grants to the public an interest in that use, and must submit to be controlled by the public for the com. mon good, to the extent of the interest he has thus created. He may withdraw his grant by discontinuing the use; but, so long as he maintains the use, he must submit to the control.

2. Through limitations in franchise grants. ${ }^{3}$ Carriers perform franchise conditions by complying with the changing concepts of adequate service, reasonable rates,

\footnotetext{
${ }^{2}$ See Report of Earexgency Bonrd Appointed Sept. 27, 1938 undex 510 of Railway Lasox Act for history of prage trends since s916 and explanation of mechanics of adjusement. This report found wage levels generally not too high but containing individual excesses which it implied the roads might adjust individually rather than via a general horizontal decrease.

Munn v. lllinois, 94 U. S. 113,126 (1876).

- Franchises are mandatary or permissive depending on construetion. Obligations become attached to a franchise originally "permissive" when grantee exercises it and public dependence thereon develops. Franchises convey only those powers expressly conferred or necessarily implied. Thus the power to transfer the franchise by lease or otherwise cannot be implied. Courts construe franchises strictly against the grantee and in light of broad public policy. Legislatures impose new duties by general or special amendatory statutes in exercise of the state police power, which the legislature cannot abdicate. Commis. sions enforce franchise duties under statutory rules.
} 
and absence of discrimination. The statutes and cases have dealt chiefly with the last two of these, for we have generally had an oversupply of railroad facilities rather than a lack. Yet to render adequate public service is the foremost obligation; it persists as long as the carrier elects to enjoy the benefits of its franchises. Public protection is not limited to constant riders and shippers; it includes the suburban home owner who without the railroad would pay more for his coal and get less for his house, the wife of the employee in the local factory which would close if the railroad stopped, and the butcher, the baker, the candlestick maker who supply commuters and shippers. Waite spoke of the "community at large," "the common good," of granting "to the public an interest in the use."

Of course the duty has limits. "Apart from statute or express contract, people who have put their money into a railroad are not bound to go on with it at a loss if there is no reasonable prospect of profitable operation in the future."4 Such compulsion would be taking private property without compensation in violation of the Fourteenth Amendment. However, even though a specific service fails to cover its separate costs, it may be properly required when it is necessary, when the carrier's franchises are generally profitable, and if the weighing of private and public interests warrants a finding that it is a reasonable burden on the carrier's profitable franchises, $\$$ an indirect income tax or rent reserved to the franchise grantor.

State commissions nowadays measure the franchise duties under broad statutory powers delegated by the legislatures. Federal regulation is based on Section I (I8-20) of the Interstate Commerce Act, which prevents a road from abandoning a line without an I. C. C. permissive certificate stating that such abandonment is compatible with public convenience and necessity as to interstate commerce. The intrastate service may not be abandoned without a state certificate unless the I. C. C. finds that continuing the losing intrastate service is an "unreasonable burden on interstate commerce." The I. C. C., however, exercises no jurisdiction over abandonments of services when the line is retained for other services. Thus a road may cut trains in interstate or intrastate commerce from 100 per day to $x$ per week without any 1 . C. C. certificate. State commissions regulate service as well as line abandonments.

However adequate these state and federal service protection mechanisms may formerly have buen in a generally expanding economy, they do not today appear to secure the public interest against the new pressures of drastic reorganization. These pressures jeopardize all owned or leased lines and services which can be legally shown

\footnotetext{
'Holmes, J., in Bullock y. Railroad Commission, 254 U. S. 513 (1921), citing Brooks-Scanlon Co. צ. Railroad Commission, 251 U. S. 396 (1920).

'Southern Ry. v. Hatchett, I74 Ky. 463, 192 S. W. 695 (1917), discusses the cases distinguishing between the right to abandon an entirely insolvent road and the duty to operate losing branches of 2 solvent road. See also Brownell v. Old Colony R. R., 164 Mass. 29, 4 I N. E. 107 (1895).

- This control is exerted over intrastate commerce only to free interstate commerce from unreasonable burdens. See Brandeis, J., in Colorado v. U. S., 271 U. S. 153,163 (1926).

${ }^{7}$ Public Convenience Appl., Kansas City Southern Ry., 94 I. C. C. 691 (1925); see Proposed Abandonment, Morris \& Essex Ry., 175 I. C. C. 49 (193I).
} 
by a segregation formula or otherwise not to pay their separate costs, despite public necessity, despite system profit from other services on the same lines and even at the same stations, and despite system profit from through traffic diverted away from the particular line in furtherance of consolidated system concentration. ${ }^{8}$

How the new pressures operate is shown below by a simplified presentation of the case of the Old Colony lines in the current reorganization of the New York, New Haven and Hartford Raiiroad Company, a case notable for the magnitude of the services affected and illustrative of the difficulties in achieving strong, articulate representation of the user interest. Following this case history, a proposal for implementing user representation will be presented.

\section{III}

Before 1893 the Old Colony Railroad Company 9 operated a large integrated system in southeastern Massachusetts, with three lines to Providence, and rail-water Long Island Sound lines to New York. It was the only railroad in Fall River, New Bedford and Brockton, the principal one in Boston, and important in Lowell, Fitchburg, and Providence. With one exception its lines embraced the entire present New Haven system in eastern Massachusetts. Yet it was then in no way dependent upon the New Haven, for it had excellent through connecting routes west, especially via the Boston \& Albany line, and south via its own Fall River and New Bedford boat lines, but none via the New Haven.

During 1893 the entire Old Colony properties and franchises were transferred to the New Haven by lease for 99 years, the maximum term permitted by Massachusetts statutes. The $7 \%$ return on Old Colony stock provided in the lease attests the value of the Old Colony franchises. The Old Colony then went out of the railroad business, but its securities improved their seasoned stature in the market, and they stayed off the New Haven's balance sheet. Yet, as Commissioner Eastman has stated, "a lease for 99 years is often regarded as the equivalent of ownership in fee, and the Old Colony was treated by the New Haven as if it were so owned."10

The New Haven acquired full and exclusive use of the properties for a term longer than any man's lifetime. The asset which provided the going concern value, the operating organization, was turned over completely and permanently. The New Haven acquired a majority of Old Colony stock. It transferred the Old Colony's New York steamboat lines to another New Haven subsidiary. It integrated Old Colony rail operations with its other lines, merging facilities, scrapping duplications, and altering traffic channels, all in the interest of system efficiency and in the quest

\footnotetext{
- While over 35,000 miles of road are leased, this is by no means just a leased line problem. All segments are vulnerable which can be made subject in reorganization to a segregation of earnings and expenses which does not show a net income. Current practice divides lines into segments according to mortgages and leases. The resulting segments, if legally logical, are frequently incapable of separate operation.

-The name refers to the old Plymouth Colony, now southeastern Massachusetta.

${ }^{10}$ Eastman, C., dissenting in New York, N. H. \& H. R. R. Reorg., Fin. Doc. I0992 (March 22, 1940) mimeo, rep. at 178 .
} 
for maximum net income for the New Haven. Several Old Colony routes from Boston to New York were dried down, with others, to one concentrated route over the Old Colony's leased Boston \& Providence line, ${ }^{11}$ which was then promoted as part of the New Haven's "Shore Line." Traffic was routed away from the historic nonNew Haven Old Colony through routes. The Old Colony Company disappeared from public concern, and on its former lines the engines, cars, signs, tickets, bills of lading, time tables, route guides, conductors, and paychecks all bore, and still bear, only the proprietary label of the New Haven.

The user interest in the Old Colony area obtained the protection of the entire New Haven system earnings by franchise transfers under the 1893 lease, to which Massachusetts gave the necessary consent. The New Haven quietly performed the service for over 45 years, while the area grew industrially and resortwise, and became inseparably grafted by the railroad into the metropolitan scheme of Greater Boston. Far more passengers still ride into Boston over the former Old Colony lines to America's heaviest-volume steam station than ride over the New Haven's line into New York. On those Old Colony lines are the chief system freight terminal area, the largest system shipper, numerous famous industrial plants, a great world portand incidentally the system's only steam locomotive repair shops. The New Haven cannot be operated without parts of those lines.

Such a service might seem invulnerable, but there follows a chronological entmeration of the steps by which reorganization has placed it in jeopardy.

1. On October 23, 1935 the New Haven petitioned the United States District Court for the District of Connecticut for reorganization under Section 77. The court appointed trustees for its properties, who tentatively continued paying Old Colony rentals. The general public was justifiably not alarmed. It seemed that the splendid property would be relieved at last from extravagant debt burdens created in the early twentieth century. Old Colony stock climbed back from its 1935 low of 39 to yo by March 30, 1936; its bonds rose to 90.

2. On June $\mathrm{I}, \mathrm{I} 936$, the trustees, on the basis of earning power studies prepared for them, rejected the lease as unprofitable, thus putting on Old Colony the primary duty of entering and operating its railroads. Service would have stopped had the lease rejection entailed cessation of operation by the New Haven, for, although deferentially termed a "carrier" in subsequent proceedings, the Old Colony was still just a bookkeeping device. It had neither funds, organization, nor equipment to operate its railroads, and the latter had become unworkable apart from the system. Accordingly, on June 3, 1936 the court ordered the New Haven trustees to continue operating the lines entirely as before, but, retroactively since October 23, 1935, for the account of the Old Colony, as authorized by subsection (c) (6). ${ }^{12}$

\footnotetext{
${ }^{21}$ The line of the Boston \& Providence R. R., which was leased to the Old Colony in 1888 for 99 years, was part of the Old Colony system turned over to the New Haven in 1893 .

${ }^{12}$ This paragraph puts the duty to operate upon lease rejection in the lessor "unless the judge, upon the pecition of the lessor, shall decree after hearing that it would be impracticable and contrary to the public interest for the lessor to operate the said line, in which event it shall be the duty of the lessee to
} 
3. Simultaneously the court approved the Old Colony's petition for reorganization in the same proceedings as a stock subsidiary of the New Haven. On June 8 , 1936 the three New Haven trustees were appointed trustees of the Old Colony. ${ }^{13}$

4. On June 1,1937 the New Haven proposed a plan of reorganization providing for acquisition of all of Old Colony's properties on terms which included the exchange of two new New Haven shares for each outstanding Old Colony share. Old Colony interests demanded more, and I. C. C. plan hearings went into the controversial measures of Old Colony's severance or strategic value, the contribution of its traffic to system earnings, value of particular facilitics, potential economies, etc.

5. The trustees needed a basis for charging the Old Colony for operating its roads. Their studies were reduced to a segregation formula, a device for cutting the patient in two and allocating to the part called Old Colony separate revenues and expenses and a share of the joint items. "No adequate formula can be devised for such a purpose," 14 and this ene created controversy. The I. C. C. on reference found that, while the formula failed to recognize sevcrance and contributory value and the value of particular facilities, those items were properly left for consideration in the plan hearings. ${ }^{15}$ The I. C. C. found the formula "as fair and equitable as circumstances will permit," ${ }^{16}$ but it was careful to state also that its recommendations were "in no wise intended to express any views with respect to the use of the results obtained from the application of the formula or the weight to be given such results."17 This "approval" was issued April 15, 1938, and confirmed by the district court May 25. No appeal was taken by the Old Colony.

6. On July 18,1938 the court approved trustees' accounts charging the Old Colony with over $\$ \mathrm{II}, 000,000$ for advances, representing very largely deficits segregated under the formula. An appeal was then taken, but the Circuit Court of Appeals held that it was too late for Old Colony to attack the formula. ${ }^{18}$ The operating deficits were allowed as administrative expenses against the Old Colony estate with priority over

continue operation on or for the account of the lessor until the abandonment of such line is authorized by the Commission in accordance with the provisions of Section 1 of the Interstate Commerce Act as amended."

${ }^{18}$ The New Haven trustees were ordered to continue operating the Old Colony in the system, quite as before, but filing separate accounts. As the Old Colony's trustees they have contested those accounts and represented its side in the litigations through separate counsel. Appointment of identical men for both posts has caused avoidable criticism, but its vice lies not in any partiality but in the fact that their enforeed . impartiality prevents Old Colony from having the partial, aggressive management it deserves if it is to be separately charged. See note 24 , infra. Since the added income which a separate Old Colony could obtain is a factor in the rcorganization plan negotiations, this vice is mitigated as to the sreurity holders but not as to the public

The absence of separate trustees renders the case analogous to one where the lines involved are owned outright, even though mortgaged, for no separate operating trustees would there be appointed. Nor would these always be special security holders counsel to argue on behalf of the lines.

1" Eastman, C., dissenting, in New York, N. H. \& H. R. R. Reorg., Fin. Doc. 10992 (March 22, 1940) mimeo. rep. at 180 .

${ }^{13} \mathrm{New}$ York, N. H. \& H. R. R. Reorg., 224 I. C. C. 723,729 (1938).

10 Id. at 732 .

${ }^{27}$ Id. at 725 .

${ }^{18}$ Palmer v. Palmer, 104 F. (2d) 16r (C. C. A. 2d, 1939). 
the Old Colony mortgage. Deficits have continued annually. Old Colony stock has fallen below 50 cents a share.

7. After the June 1937 plan hearings, the 1. C. C. examiner found that no reorganization plan could be accomplished because of the drastic mid-r937 recession.

8. Meanwhile the trustees turned to economy. Several minor abandonments were consummated with I. C. C. approval; other discontinuances and curtailments were made without the necessity of such approval. In some cases highway transport was substituted. The former Old Colony steamboat lines to New York were abolished (although competing non-New Haven lines are able to continue). This system economy deprived Old Colony lines of considerable through "overhead" traffic, as did further route concentrations which were effected.

9. On December 28, 1937, the trustees applied to the Massachusetts Department of Public Utilities for authority to stop passenger service to 88 stations, without stopping freight service. The D. P. U. commenced lengthy hearings.

10. On June $20,193^{8}$, the savings bank bondholders' committee and the trustees both prayed the district court for authority to close the station service regardless of the D. P. U. The court notified the state, which appeared in the hearing (the first appearance in this chain of court and I. C. C. proceedings by a public agency) against the petition but did not produce witnesses, cross-examine, or argue against the court's jurisdiction. The order was issued, ${ }^{19}$ the station service stopped, and the state appealed. An unpaid legislative commission was appointed to investigate.

II. On July 19, 1938 , the New Haven trustees with court approval performed one of their two main functions as Old Colony trustees by rejecting the Boston \& Providence lease of IS88, since that line had operating deficits under the formula.

12. On January 16, 1939, the Circuit Court of Appeals held the 88 stations order invalid as beyond the court's jurisdiction. ${ }^{20}$ The trustees appealed, and the stations remained closed.

13. On May 3I, 1939, the Old Colony filed an amended plan of reorganization providing for abandonment of the main owned lines of the Old Colony, the so-called "Boston Group," including the heaviest-traveled railroad into Boston, which after the curtailments still had 121 passenger trains and large industries including one plant now employing 17,000 men: The New Haven in its simultaneous amended plan announced that it was now. "unwilling" to acquire the Old Colony unless the passenger service on the Boston Group ceased, but it proposed to acquire the Boston \& Providence directly (short-circuiting the Old Colony) for a high consideration, including waiver of the segregation deficits.

\footnotetext{
${ }^{10} \mathrm{New}$ York N. H. \& H. R. R. Reorg. Order No. 289, July 7, I938 (D. Conn.). The order had precedents. New York, S. \& W. R. R. Reorg., Orders Nos. 29, 32, Nov. I937 (N. D. N. J.); Fonda, J. \& G. R. R. Reorg., Order, March 19, 1938 (N. D. N. Y.), discussing authorities. The theory of the order was (1) exclusive bankruptcy jurisdiction to effect reorganization; (2) prevention of reorganization by segregation formula deficits; (3) reduction of those deficits by the discontinuances. The order applied also to stations on owned lines, subject to divisional mortgage segregation. See Transcript of Hearings on Petition for Order No. 289.

${ }^{20}$ Converse v. Massachusetts, 10I F. (2d) 48 (C. C. A. 2d, 1939).
} 
14. On June 14, the trustees summarily posied noices of complete passenger discontinuances on the Boston Group in September, acting under general court authority to take steps toward economy but without any special authority.

15. These notices threw the area and the Boston State House into an uproar of confusion, resentment, and panic. The legislative commission reported hopelessness and expired. The attorney-general threatened to have New Haven franchises revoked. A special committee recommended a new unpaid legislative commission to the governor, who pleaded with the trustees to await the new commission's report. The trustees petitioned the court for instructions; the latter persuaded the trustees and the legislative commission (not the D. P. U.) to agree on negotiations for compromise, the discontinuance to be postponed until January, I940 and the trustees free to bring abandonment proceedings.

16. At the new plan hearings in June, 1939 the presiding commissioner declined to consider the abandonment provision without the formalities of an I. C. C. abandonment proceeding.

17. November 6, 1939 the Supreme Court affirmed the Circuit Court of Appeals in the 88 stations case, holding that the bankruptcy did not give the judge power to supervene the state's normal regulatory power, except in a plan of reorganization. ${ }^{21}$ The D. P. U. then postponed an order to reopen the 88 stations until the trustees could present proper evidence.

18. The trustees continued private conferences with the new legislative commis sion concerning a reduced "interim schedule" for the Boston Group, but during the conferences they started an I. C. C. abandonment petition under Section I(18).

19. On November 30 , the Old Colony filed a second amended plan containing provision for amending the charters of the Old Colony and the New Haven so that neither would be bound to operate passenger service anywhere on the Old Colony.

20. In February, 1940 the D. P. U. ordered $3^{2}$ stations out of 88 finally reopened, and in March approved a reduced service of 72 trains instead of 121 , estimated to save \$500,000 per year.

21. March 16, I940, the I. C. C. opened abandonment hearings. The trustees presented a case on behalf of Old Colony security holders on the theory that they were saddled 'with the trustees' segregated deficits as the sole measure of operating cost which would devour their estate unless abandonment were granted.

25. As of March 22, 1940, the 1. C. C. approved a plan of reorganization for the New Haven recommending inclusion of the Boston \& Providence but not of the Old Colony proper as to the status of which decision was deferred. ${ }^{22}$ Commissioner Eastman wrote a vigorous dissent, castigating the segregation formula as a measure of value. Petitions for reopening were filed in May and argument thereon was heard June 27, I940, when the Old Colony again urged its plan to merge the roads with the antipassenger charter amendments. The petitions to reoper, together with the abandonment case, are pending.

"Palmer v. Massachusetts, 308 U. S. 79 (1939).

$"$ New York, N. H. \& H. R. R. Reorg, supre note 10. 
IV

This chronology shows how the reorganization maneuvers have established 2 situation where, as things stand now, the Old Colony service has been cut off from the support both of the New Haven, despite the consolidation of 1893 , and of the Boston and Providence, despite the consolidation of 1888 . This service is even deprived of the strength of an independent Old Colony, for the sole measure of its right to support used thus far in both the 88 stations order and the abandonment proceedings is the segregated Old Colony deficits. In the abandonment case the Old Colony interests, while regretting that they were unable to prevent these deficits from being charged as prior liens or to contest the formula, asserted that, right or wrong, the deficits were being charged against them and were not open to attack. ${ }^{28}$ Hence, under the most liberal view of due process, any requirement of continued operation of any losing service at their expense was confiscation.

This attitude may be understandable, but certainly its assumptions are not axiomatic. If, for purposes of service abandonments, the fiction is to be indulged in that the Old Colony is a separate carrier, then must its status be determined by a formula devised for allocations of system revenue and costs? Instead, should it not be entitled to a formula reflecting advantages which would be sought by a management primarily interested in the Old Colony's welfare rather than, as now, in the system welfare? Important among these would be (a) diversions of through freight back to the old routes whereon the Old Colony, rather than the system, would get maximum return, ${ }^{24}$ and $(b)$ divisions of through rates with the New Haven under the principles of Section ${ }_{15}(6)$ of the Interstate Commerce Act, which permit the I. C. C. to fix divisions among separate carriers giving due consideration to, among other things, "the amount of revenue required to pay their respective operating expenses, taxes, and a fair return on their property ... . and the importance to the public of the transportation services of such carriers ... and any other fact or circumstance which would ordinarily, without regard to the mileage haul, entitle one carrier to a greater or less proportion than another carrier"? This was one of the grounds on which the Old Colony tried to have the segregated deficits through 1937 set aside because the formula ignored this principle, but, as noted, this attack was held procedurally too late. ${ }^{25}$ Should the public be bound by this limitation?

The same opinion also stated that the question was beside the point, because the Old Colony did not have the status of a separate carrier necessary to invoke Section 15(6). ${ }^{28}$ If the realities are to be faced and the integral position of the Old Colony lines in the system frankly recognized, then why should not their service be accorded the benefit of continuing system support? It is by no means clear that subsection

\footnotetext{
${ }^{21}$ Old Colony R. R. Abandonment Hearings, Fin. Doc. 126r4, Rec., passim, esp. pp. 13, 155-156.

"Railroad agents seek maximum traffic and revenue for their system. The New Haven system roceiven greatest revenue and mileage from Old Colony western freight when routed via the New Haven to the Hudson. The Old Colony receives much more under the formula vis its old non-New Haven routes west. Since these give the New Haven system much less, agents on the Old Colony do not prefer them.

as Palmer v. Palmer, supra note 18.

Id. at 165 .
} 
(c) (6) permits the New Haven to abandon the lines without an I. C. C. adjudication that the New Haven is not able to support them as part of its system. ${ }^{27}$ Should not the lines at least get the support of the concededly heavy system earnings contributed by Old Colony's traffic on the rest of the system lines? Or certainly that portion which the system would lose if the Old Colony were really severed? Should the users be denied any system status accorded Old Colony security holders. ${ }^{28}$

The merits of these contentions await determination; it is enough here to show that there are grave and subtle controversies, too many of which were resolved against the user interest before that interest attained recognition. True, the attorney-general obtained the overthrow of the 88 stations court order. But no public advocate has appeared in any segregation formula proceeding, and the 88 stations case left open the device of abandonments via a plan of reorganization. Nor has any of the decisions placed limits on the use of the formula in the I. C. C. abandonment case.

Public officials in Massachusetts have been confused. They properly were not elected for knowledge of the esoteric concepts and techniques of railroad reorganization, and for four years they had no firm standing in the chain of proceedings. Their freedom of practical action has been hampered by statutory limits on their powers and also by business and political requirements of their offices. They are all busy men. They cannot wade into this railroad snarl and urge tax reductions, labor cuts, rate increases, or service reductions without danger of political embarrassment. The public interest is manifold, and its branches conflict.

\section{$\mathbf{v}$}

In late 1939 a small group of people who themselves actually needed the railroad, formed an organization for the sole purpose of representing exclusively the user branch of the public interest. The Old Colony Commuters \& Shippers League ${ }^{20}$ follows in the tradition of Brandeis' and Eastman's Public Franchise League of an earlier day in Boston. ${ }^{30}$ The League now has over 1200 members, including both individual citizens and business corporations, and has brought important civic groups into active alliance.

The League had no panacea but was determined to secure adequate and stable service and had faith that by clearly and imaginatively exploring the complex legal

${ }^{27}$ Cf. Meck, The Problems of the Leased Line, infra p. 512, and, for greater detail, Meck, Railroud Leases and Reorganization: II (1940) 49 YALE I. J. 1401, 1403. See also. Friendly, Amendment of the Railroad Reorganization Act (1936) 36 Cos. L. Rev. 27, 48. Cf. Webster \& Atlas Nat. Bank v. Palmer, III F. (2d) 215,218 (C. C. A. 2d, 1940).

${ }^{28}$ The segregated deficits are not the basis on which the capital value to be given Old Colony security holders in New Haven reorganization securities will be determined. Against them will be offset the severance value to the New Haven, i.e., income concededly now accruing to New Haven from trafic on its own lines which it would not have if it lost the Old Colony. Also in the measure will be the damages allowed already to some $\$ 50,000,000$ (a sum greater than its entire 1936 capitalization) for lease rejection and defaults. Thus the rejection was not a true divorce as to the Old Colony security holders but created for them a substitute position directly in the system. While the priority of the deficits is superficially alarming, the final plan will include items deemed fair and equitable in light of the history, and the I. C. C. plan for the Eoston \& Providence suggests that ultimately the segregated deficits of Old Colony will likewise be given short shrift.

"Originally "Old Colony Commuters League." $\quad{ }^{30}$ See LJEF, Brandets (1936) 66 ff., 76 ff., 210. 
relations and economic facts a way would be found to make the railroad work. It preempted the position of chief speaker for the user interest and its general committce of leading citizens from all affected towns is able to say what service is really needed and what is not. Therefore it urged the D.P. U. not to reopen most of the 88 stations as a fair sacrifice to save the remaining service. As to that, it collaborated with the railroad in securing the reduction in trains from 121 to 72 . It has appeared in town hearings for railroad bus permits and overcome natural prejudice against the petitioners. It has encouraged the reluctant railroad to petition to save \$150,000 by automatic grade crossing installations. It cooperated in a campaign by the Boston wing in the railroad organization to increase freight use and has pledged all League members to use the railroad whenever possible. It has distributed a series of informative circulars, 10,000 at a time.21

Although it found that Massachusetts opinion had cast the New Haven and its trustees as villains in the piece, the League recognized that the Old Colony is geared only to be part of the New Haven and that therefore the major objective must be to persuade, or if necessary to force, the New Haven to adopt and merge the Old Colony lines legally as well as factually. Hence with some trepidation (for none of its active members had ever been in a railroad reorganization) the League secured general intervention in the I. C. C. plan proceedings to advocate what it deems to be "compatible with the public interest." 22 This intervention, which unfortunately came after the record had been closed, seems to have set a precedent. The League filed exceptions to the proposed November plan and, after the I. C. C. March, $1944_{2}$ plan was issued, petitioned for a review and reopening for insertion of new matter concerning Old Colony value in the system. In June it argued on that petition, which is pending. The League's biggest efforts have been in the I. C. C. abandonment case where it presented the case for local actual necessity and is trying-unsuccessfully. 80 far-to disestablish the trustees' theory of the case. This case is likewise pending.

A special contribution of the League has been to act as a magnet, bringing parties in from extreme to conciliatory positions. Quietly and continually, but apparently without antagonizing, it suggests constructive moves for other parties to make. It seeks to reach beyond the normal ambit of reorganization. Not permitted in the 1. C. C. abandonment hearing to discuss uitra-modern motor cars with possibly oneor two-man crews instead of four- or five-man crews on present minimum steam trains, the League is promoting their consideration in other ways. ${ }^{32}$ It is encouraging local property tax reductions by towns and hopes to present a new general reform

\footnotetext{
"One purpose of these circulars was to combat suspicion that the League by aiding the railroad had become a railroad stooge.

3257 (d) Ist par.

"The League rocently invited local public and press officials to $x$ demonstration of the new cars on the N. Y., S. W W. in New Jersey which are expected to be operated for 35 cents per mile, a figure far lower than any conceded by the Ner Haven.

Coordination with other carriers by rail (including transit lines) and highway is being considered by the League, including the utilization by the B. \& A. of the Old Colony's Boston coach yard instead of its own, an economy estimated, in a 1935 report by both roads to the Federal Coordinator, to provide $\$ 235,000$ annual savings, plus release of valuable land ripe for civic development.
} 
railroad tax statute to the next legislature which will aid insolvent roads. Also it hopes to have the railroad segregate great non-railroad landholdings, perhaps into a separate subsidiary, to take the burden of Greater Boston's increasing realty taxes out of the railroad accounts. The League hopes, if heavy steam trains can be removed, to initiate labor adjustments which will be helpful to all sides, including labor. ${ }^{34}$

\section{VI}

The League's aspirations are definitely off the beaten track. But why should not such things be gone into in a railroad bankruptcy if it will save service? One excuse is the traditional limits of reorganization scope to debtor-creditor adjustments. The new deeper reorganizations demand broader techniques. Another is the fact that outlets for the new reorganization pressures to develop earning power are blocked in other directions than service abandonments. A third is the domination of reorganizations by busy lawyers who too often do not really know their properties. Many have never seen them; most have never really analyzed operations, traffic opportunities, rate policies, labor agreements, or cooperative economies with other roads. Even when the lawyers are railroad experts, they wring the statutes and precedents for brilliant legal devices to prefer their clients above other groups in reorganizationand that is what they are hired to do. However valid these tactics, they do not solve the service problem of the railroad.

The lawyers and courts rely on the trustees for smart management. Other than the presidents of the roads, these usually come in from such non-railroad work as insurance executiveship and must themselves rely heavily on notably conservative organizations of men largely trained from youth in compartmentalized routines, ${ }^{85}$ to which the reorganization has added shackles of fear. Partisan groups also engage the services of economist-advocates, whom they qualify as experts to present data and analyses in favor of their views.

While the district judges do not pretend to know the minute ramifications of the sprawling roads in their custody and work under the pressure of a Supreme Court mandate of speed, "te "the judicial process in bankruptcy proceedings under Section 77 is, as it were, brigaded with the administrative process of the Commission" 37 in many aspects where the public interest is affected. But the 1. C. C. is a tribunal whose primary function is as arbiter,,$^{38}$ and even in that function is badly overworked. ${ }^{30}$

\footnotetext{
"2 The League is not anti-labor. It agrees with the Coordinator that labor-saving changes with humane safeguards for men displaced is, considering all factors, in the best interests of railroads and labor. See Fed. Coordinator of Transportation, 4 th Report (1936) 73.

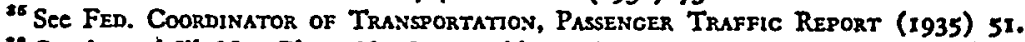

"Continental Ill. Nat. Bk. \& Tr. Co. v. Chicago, R. 1. \& P. Ry., 294 U. S. 648, 685 (x935).

${ }^{27}$ Frankfurter, J., in Palmer v. Massachusetts, 308 U. S. 79, 87 (1939).

"See Nelson, Representation of the Consumer Interest in the Federal Government (1939) 6 Law \& CONTEMP. Proz. 151, 156. "The Commission [has] increasingly emphasized its judicial function at the expense of its role as public defender. . . . This tendency appears to have been incvitable. . . It is obviously impossible for the same group of officials to act as impartial arbiters and as zealous defenders of one of the parties involved. . . . As a result, the [consumer interest] has been largely unrepresented at court and has lacked an effective voice in the Commission's deliberations."

${ }^{20}$ Dembitz, Progress and Delay in Railroad Reorganizations Since 1933, supra, p. 415.
} 
The New Haven case-there will be many like it ${ }^{40}$ - shows that the "consumer" interest needs a more positive form of representation. However this interest may be organized, it calls for an able and courageous spokesman, free from financial and political entanglements, who in advocating its cause against the reorganization pressures will ensure that squeezing out the users is not taken as the road of least resistance. In doing this the spokesman must not hesitate to conciliate rigid partisan insistences or to promote vigorous, even unorthodox, operating improvements, tax and labor adjustments, conrdinations, public aid devices, etc. His legal status in the proceedings must be unquestioned. His work and that of an adequate staff should be recognized as valuable to the reorganization and entitled to reasoriable support currently from the railroad estate.

Reliance upon a volunteer group of citizens organized to protect their rail service, such as the League in the New Haven case, will seldom result in meeting the foregoing specifications. The League's germination was a happy accident. Spontaneous generation of such groups will be infrequent. If they arise, time-consuming intricacies will limit their effectiveness. If the unccngenial task of soliciting private contributions is to be avoided, the court must be persuaded to permit intervention in the proceedings on a basis allowing compensation; yet this will present difficulties when more than one user representative emerges. ${ }^{\text {a1 }}$

The problem of consumer advocacy has plagued other fields of government regulation. In the NRA, the AAA, and the Bituminous Coal Commission a permanent consumers' counsel was made part of the regulatory mechanism. ${ }^{42}$ It would seem that in railroad reorganizations this device would not serve best, for the railroad geography in each area is individual and the problems of each area are likewise diverse. The consumers' agency must therefore combine capability with knowledge of local conditions and procedures, and it should bring a frest approach into each case. This could scarcely be expected of a section in any department or bureau.

Fortunately a simple solution is at hand, for which no new legislation is needed. Under the existing statute ${ }^{43}$ the I. C. C. may adopt the practice of appointing in all cases where conditions warrant a special users' counsel with a staff. The counsel should preferably be resident in the general region affected and be advised by committees representative of the various localities and classes of service involved. The

${ }^{\Delta 0}$ As pressures increase, regional consolidations seem inevitable, concentrating through traffic on the most efficient routes to a degree approximating current concentration of through express and parcel post traffc. This will produce savings, estimated in the Prince-Barriger Plan of 1933 at $\$ 2,000,000$ daily. Yet it will withdraw from more lines the support of through traffic and threaten the integrity of their remaining service.

"There is the risk of duplication of argument, time, expense. Towns and civic boards have separate counsel. Oecasionally, too, a member of the lunatic fringe will gather sufficient backing to enable him to assert representation of a public interest. Sound exercise of judicial discretion is a better protection against these dangers than formulation of a rule excluding all except state officials. Incidentally, the latter, in addition to their other difficulties, will $b$ especially handicapped where the particular service affected involves two or three states.

"Discussed in Nelson, supra note 38.

${ }^{43} 577(c)(12)$. 
1. C. C. is better equipped than courts or state political officers to select men for the post with the qualifications which have been outlined."4

State officialdom should appreciate relief from sole responsibility for advocating the public interest in these specialized and occasionally embarrassing proceedings. Those financial interests which seek rehabilitation of the road as a going concern rather than mere salvage for a class of system investors should find the special counsel's objectives compatible with their own. Finally, both the court and the Commission itself should welcome the addition of a capable and authentic users' spokesman to assist them in their determinations of the public interest.

sEThe district court would, however, have to approve the employment. Section 77(c)(12) provides: "... the judge... may make an allowance to be paid out of the debtor's estate for the actual and reasonable expenses incurred in cornection with the proceedings and plan and reasonable compensation for services in connection therewith by ... such assistants as the Commission with the approval of the judge may especially employ." 